\title{
Novel potential biomarkers with predictive power on response to therapy in cardiac resynchronization therapy - cardiac oxidative stress assesment
}

\author{
Sergiu Sipos', Radu Ciudin', Corina Grigore², Carmen Ginghina'
}

\begin{abstract}
CRT represents the transition from the heart rhythm therapy, started more than 60 years ago with the first pacemakers, to the optimization therapy of myocardial contractility in heart failure. It is estimated that about a quarter of the population of patients with heart failure have electrical and mechanical criteria for cardiac asynchrony. They are the target of resynchronization therapy. The current indications for resynchronization therapy use basic selection criteria, without having high predictive power in terms of response to treatment. About one-third of patients undergoing resynchronization are found to be non-responsive to therapy. In this study we tested a new direction in our effort to increase the number of post-resynchronization beneficiaries, using markers of oxidative stress in patients with heart failure, assessed before and after intervention, with promising results.
\end{abstract}

Keywords: heart failure, cardiac resynchronization therapy (CRT), response to therapy, oxidative stress.

Rezumat: Terapia de resincronizare cardiacă (CRT) reprezintă trecerea de la terapia ritmului cardiac, începută acum mai bine de 60 de ani cu primele stimulatoare cardiace, la terapia de optimizare a contractilității miocardice în insuficiența cardiacă. Se estimează că aproximativ un sfert din populația pacienților cu insuficiență cardiacă prezintă criterii electrice și mecanice de asincronism cardiac. Aceștia reprezintă ținta terapiei de resincronizare. Indicațiile actuale ale terapiei de resincronizare folosesc criterii bazale de selectie, fară putere predictivă mare în ceea ce privește răspunsul la tratament. Aproximativ o treime dintre pacienții supuși procedurii de resincronizare se dovedesc a fi non-responderi la terapie. În acest studiu am testat o nouă direcție în încercarea de a crește numărul beneficiarilor post-resincronizare, apelând la markeri ai stresului oxidativ, înainte și după implant, la pacienți cu insuficiență cardiacă, cu obținerea unor rezultate promițătoare.

Cuvinte cheie: insuficiență cardiacă, terapie de resincronizare cardiacă, răspuns la terapie, stres oxidativ.

\section{INTRODUCTION}

Over the past few decades, clinical and experimental studies have provided substantial evidence that oxidative stress, defined as an overproduction of reactive oxygen species (ROS) relative to the body's antioxi-

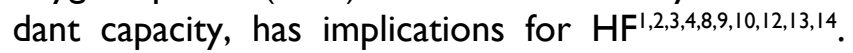
Excess ROS causes cellular dysfunction, protein and lipid peroxidation ${ }^{8}$, and DNA damage and can lead to irreversible damage and cell death (processes described in a wide range of cardiovascular diseases). The importance of oxidative stress is increasingly emphasized in terms of a physiopathological mechanism of cardiac remodeling, responsible for the emergence and progression of IC ${ }^{15}$. Specifically, ROS can directly

\footnotetext{
' „Prof. Dr. C.C. Iliescu” Emergency Institute for Cardiovascular Diseases, „Carol Davila” University of Medicine and Pharmacy, Bucharest, Romania

2 „Coltea” Clinical Hospital, „Carol Davila” University of Medicine and

Pharmacy, Bucharest, Romania
}

affect contractile function, modifying proteins that play a role in excitation-contraction coupling ${ }^{16}$. Furthermore, ROS activates a wide variety of kinases with a role in signaling myocyte hypertrophy, transcription factors and mediated apoptosis ${ }^{17}$. It also stimulates the proliferation of cardiac fibroblast and activation of matrix-metalloproteinases (MMP), which leads to the remodeling of the extracellular matrix ${ }^{18}$. These cellular events are involved in the emergence, progression, remodeling and, finally, in the working myocardium dysfunction. The balance between ROS production and their removal from the body by using specific antioxidant mechanisms defines the „redox” system. Increased oxidative stress is defined as an excess production of ROS relative to levels of antioxidants. ROS are hi-

\section{Contact address:}

Sergiu Sipos, MD, „Prof. Dr. C.C. Iliescu” Emergency Institute for Cardiovascular Diseases, „Carol Davila” University of Medicine and Pharmacy, Bucharest, Romania.

E-mail: sersip@yahoo.com 
ghly reactive chemical oxygen species. Their representatives are free radicals, such as superoxide $\left(\mathrm{O}_{2}-\bullet\right)$, hydroxyl radical $(-\mathrm{OH})$ and nonhydroxyl, capable of generating free dangerous radicals, such as hydrogen peroxide $\left(\mathrm{H}_{2} \mathrm{O}_{2}\right)^{10,11,12,18}$ All of these known theoretical aspects can be used for better defining heart failure patients and could be of good use when selecting the best suited candidates for CRT.

\section{OBJECTIVES}

The aim of the study was to evaluate the total antioxidant capacity and the degree of damage of the DNA structure using specific biochemical markers 8-hydroxy 2'-deoxyguanosine (8-OHdG) and total antioxidant capacity (TAC) ) in patients with low $\mathrm{EF}<35 \%$ and indication for CRT, in 3 distinct steps: sample I collected from peripheral blood at the time of resynchronization; sample 2 collected from the blood taken from the coronary sinus at the time of cardiac resynchronization; sample 3 collected from peripheral blood 6-9 months after intervention. The basis for our research was the behavior of the REDOX system in patients with heart failure ${ }^{15,16,19}$. There is a growing interest in literature for assessing the role played by oxidative stress agents in promoting organ damage, but also in determining the oxidative stress as a marker of the target organ injury severity - in our case the heart ${ }^{17,20}$. Publications we have studied conclude that there is a relationship of direct proportionality between the degree of heart failure and the level of these plasma quantifiable markers ${ }^{1-16}$. On the other hand, the vast majority of data show the low discrimination between oxidative stress markers of cardiac or systemic origin ${ }^{7,8}$. In this regard, we considered appropriate to evaluate the markers of oxidative stress in both peripheral venous blood and the central venous blood (during the implant, from the coronary venous sinus). From our observations, a single study published in Circulation in 2015 (please note that at that time our study was already underway) analyzed the levels of oxidative agents (oxidized mitochondrial RNA of myocyte origin) sampled directly from the coronary sinus vs. the same marker extracted from peripheral blood, with promising results $^{2}$. Other research looked at markers of oxidative stress extracted only from peripheral venous blood ${ }^{5,6,7}$. Our working hypothesis was based on these observations - that the level of oxidative stress is higher in patients with advanced heart failure. As such, we chose the quantification of 8-hydroxy 2'-deoxyguanosine (DNAd 8-OHdG) as an marker of oxidized myocytic DNA and we used the evaluation of total antioxidant capacity (TAC) as a measure to verify the former, well knowing that oxidative systems and antioxidants are complementary in the human body. Thus, any therapeutic intervention with impact on these patients (CRT in our case) would, on the one hand, influence the values of these biomarkers and on the other hand, it could even identify the profile of the future CRT responders.

\section{METHODS}

This prospective, dynamic, non-randomized clinical study enrolled 29 heart failure patients. These patients were admitted between 2013-20I5 in the Emergency Institute for Cardiovascular Diseases Prof. Dr. "C.C. Iliescu" - Bucharest, with indication of cardiac resynchronization. There were 22 (75.86\%) men and $7(24.14 \%)$ women, with an average age of 64 . Heart failure causes, for these patients, were divided into ischemic dilatative cardiomyopathy (DCM) and nonischemic DCM. This study involved human subjects and was approved by the Ethics Committee of the Emergency Institute for Cardiovascular Disease Prof. Dr. "C.C. Iliescu" - Bucharest. All clinical investigations were performed in accordance with the principles set out in the Declaration of Helsinki and patients were included in the study after signing the informed consent. The enrolled patients were implanted in the department of Cardiac Electrophysiology and Pacemakers within the Emergency Institute for Cardiovascular Diseases "Prof. Dr. CC Iliescu" in Bucharest, according to the present European CRT guidelines. The implant procedure was performed following the operating protocol of our Electrophysiology Department, with the goal of obtaining the optimal position of the LV lead in respect to the individual anatomical variability. No significant procedural complications were reported during implantation. During the CRT procedure, blood samples were taken simultaneously from peripheral vein and from venous coronary sinus (CS). The third blood sample was obtained after 6 to 9 months during follow-up. We took into account the absence of obvious clinical signs and symptoms of infection as well as the absence of the infectious biological picture at the time of the oxidative stress biological samples collection (for all samples). We grouped the clinical and laboratory parameters of the diagnosis, as well as those related to the procedure into 3 categories:

I) Pre-procedural parameters: NYHA functional class, 6 minutes walking test, comorbidities, opti- 
mal drug therapy, chest X-Ray, EKG, biochemistry, echocardiography analysis;

Echocardiography analysis:

- severity parameters: FE, degree of mitral regurgitation, VTDVS, AS dimensions;

- mechanical asynchronism data (presence of AV, $V V$, intra-ventricular asynchronism parameters);

- others: echogenicity of LV walls, regional kinetic disorders / affected territory;

2) Intra-procedural parameters

Device type:

- CRT-P (- defibrillator)

- CRT-D (+ defibrillator)

LV lead positioning: lateral, postero-lateral, inferior or anterior wall

3) Post-procedural parameters

Device programming:

Programming mode: VVI / VVIR; DDD / DDDR; DDI / DDIR

A-V interval: 80-90- I00-II 0- I20- I $40 \mathrm{~ms}$

V-V interval: 0-10-20-30-40-50-60-70-80 ms

Scheduled frequency: 50-55-60-65-70-75-80 / min

Re-evaluation of biochemical, ECG and echocardiographic parameters both immediately after implantation and in dynamics during the study.

Blood samples were collected in sterile vacutainers without anticoagulant. Maximum 3 hours after sampli$\mathrm{ng}$, the blood was centrifuged at $3000 \mathrm{rpm}$ for $10 \mathrm{mi}-$ nutes to obtain the serum. The serum was immediately separated, brought into Eppendorf tubes and stored at $-80^{\circ} \mathrm{C}$ until determinations were made. After thawing the serum and bringing it to room temperature, we performed the actual analisis by determining TAC and 8-OHdG biomarkers by ELISA (Enzyme-linked immunosorbent assay). The kits used in this experiment are from Abcam, USA.

As mentioned, the aim of the study was to evaluate the total antioxidant capacity and the degree of damage to the DNA structure (using 8-hydroxy 2'-deoxyguanosine (8-OHdG) as a specific biochemical marker) in patients with HF with low FE $(<35 \%)$ and indication for cardiac resynchronization, in 3 distinct stages: Sample I from peripheral blood at resynchronization; Sample 2 of blood collected from the coronary sinus at the time of cardiac resynchronization; Sample 3 of peripheral blood at 6-9 months post-intervention.

Oxidative stress determinations were performed by the competitive ELISA method: OxiSelect ${ }^{\mathrm{TM}}$ Oxi- dative DNA Damage ELISA Kit - determination of 8-hydroxydeoxyguanosine (8-OHdG) as a marker of oxidative DNA damage. OxiSelect ${ }^{\mathrm{TM}}$ Total Antioxidant Capacity (TAC) - determination of total antioxidant capacity, based on the reduction of copper (II) to copper (I) by plasma antioxidants. Chemwell 2010 EIA and Chemistry Analyzer Automated Analyzer (Awarness Technology INC, USA) was used.

\section{Statistical analysis}

The statistical programs SPSS (Statistical Package for the Social Sciences), STATISTICA and, respectively, Microsoft Excel were used for the statistical analysis of the data. The following parameters were determined: arithmetic mean of the values in the data string; standard deviation (SD); variance (how the values in the data group are divided around the average value); probability ( $P$ ); Pearson correlation coefficient.

In the case of the data groups with normal dispersion, the Student's and ANOVA's tests were used. The statistical interpretation of the analyzed results was the following:

if $p<0.05$, the difference is significant;

if $p<0.0$ I, the difference is highly significant;

if $p<0.00$ I, the difference is very high significant; if $p>0.05$, the difference is insignificant.

\section{RESULTS}

\section{Characterization of the studied population}

This prospective, dynamic, non-randomized clinical study was attended by $3 \mathrm{I}$ patients admitted between 2013-20I5 at the Emergency Institute for Cardiovascular Diseases Prof. Dr. "C.C. Iliescu" - Bucharest, with indication of cardiac resynchronization, with an average age of 64 . It should be noted that two patients were excluded from the study for reasons related to the methodology of biology products processing - hemolyzed blood that did not allow efficient centrifugation.

Regarding sex distribution, most of the enrolled patients are male (Figure I), which is explained partially by the higher incidence of ischemic DCM among males and also by the higher incidence of DCM in general, in males $(67-72 \%$ male prevalence in different studies $^{21,22,23,24,26,29}$ ).

Most patients prove to be from urban areas (58\%), have non-ischemic DCM (84\%) and have significant co-morbidities, in this order: hypertension (HBP), dyslipidemia, diabetes (DM), chronic kidney disease. Four patients had chronic lung disease. 


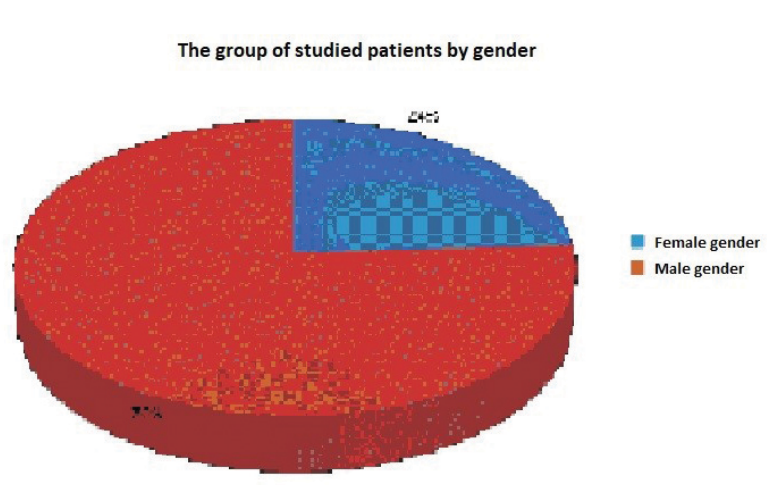

Figure I.

In terms of clinical condition, the majority (78\%) had ICC class III NYHA and $6(20 \%)$ of the 29 patients were in atrial fibrillation (AF).

With the exception of one patient, all others had optimal drug therapy.

In terms of EKG, 4 of the 29 patients had nonspecific intra-ventricular conduction disorder (NIVCD) and one had iatrogenic LBBB (VVI pacing a few years back).

The mean duration of QRS was $162 \mathrm{~ms}$, a single patient had a rather short QRS duration of $120 \mathrm{~ms}$, all the others seemed to have durations over $130 \mathrm{~ms}$.

From the echocardiography point of view, we note the presence of an average end-diastolic volume of $137 \mathrm{ml}$, an average left atrium diameter of $47.8 \mathrm{~mm}$, the presence of grade III or IV mitral valve regurgitation in $70 \%$ of subjects and increased pulmonary artery pressure (PAPs over $40 \mathrm{mmHg}$ ) in $95 \%$ of patients. $22 \%$ had type I diastolic dysfunction, $67 \%$ restrictive type and $11 \%$ pseudo-normal type. Regarding the analysis of mechanical desynchrony, $55 \%$ of the patients had apical rocking present at the time of inclusion in the study; $88 \%$ had diffuse hypokinesia of LV walls, the others had segmental kinetics disorders.

The ejection fraction (EF), as the main echocardiographic parameter for inclusion in the study was initi-

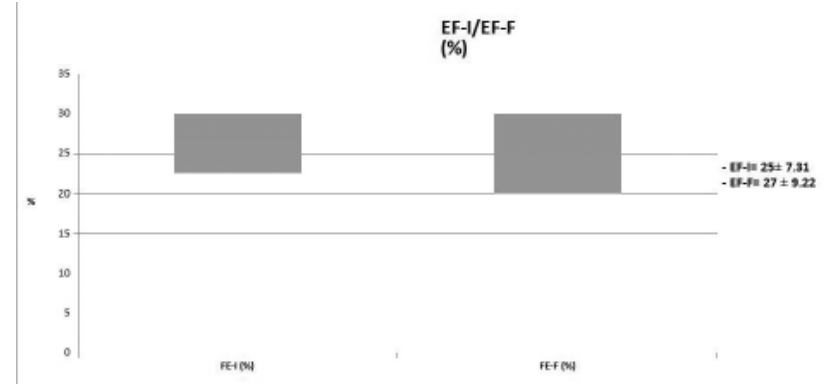

Figure 2. The mean initial EF and the later EF do no differ very much due to the decrease of value in the non-responder group, during follow-up. ally evaluated as $25 \pm 8.3$ I (SD), and in follow-up $27 \pm$ 9.22 (SD) (Figure 2).

Regarding the type of implanted device, 33\% (10 subjects) received a CRT-D device, the rest of them CRT-P.

The location of the LV lead was in $47 \%$ of cases at the mid posterior-lateral wall, $21 \%$ had a basal posterior-lateral position, $5 \%$ apical posterior-lateral wall, $12 \%$ lateral basal wall, $7 \%$ mid lateral wall, $3 \%$ anteriorlateral wall and $5 \%$ inferior wall.

Device programming was performed in DDD (R) mode in $80 \%$ of patients and VVI (R) in $20 \%$ (those with $\mathrm{AF}$ ). The average programmed heart rate (Lower rate interval) was $55 \mathrm{bpm}$. The mean programmed AV interval was $105 \mathrm{~ms}$ and the mean inter-ventricular interval was $35 \mathrm{~ms}$.

Early post-implant cardiac ultrasound optimization control was performed in all patients, aiming especially the optimization of LV filling and abolishing of the apical rocking.

We can summarize our patients profile as follows: Male patient, from urban environment, around 65 years old, with non-ischaemic DCM, with a mean ejection fraction of $25 \%$, in sinus rhythm, with complete LBBB of 160 ms duration, cls III NYHA and under optimal medical treatment. "Our patient" received a CRT-P type device with the left ventricle lead being placed in a posterior or lateral position with optimal pacing parameters. The device was programmed in DDD mode, with a short AV delay of $100 \mathrm{~ms}$ and a delay of 30 ms between left and right lead.

Regarding laboratory testing, it is important to emphasize that there was no anemia either before or after the implant. Neither the serum glucose nor the lipid profile parameters showed any significant statistically differences between the 2 distinct moments in time in which the evaluation was performed. The same observation was noticed in the case of hepatic, renal and other hematological parameters.

Uric acid is a clinical parameter of oxidative stress $^{25,26,30}$. The plasma concentration of this compound, determined at the time of cardiac resynchronization collected from peripheral blood, was slightly increased compared to the concentration determined at 6 months post-intervention, but without statistical significance (Figure 3).

As can be seen from the table below (Figure 4), the patients included in the study have slightly to moderate impaired renal function, the level of creatinine clearance being generally above $50 \mathrm{ml} / \mathrm{min}$. We do not notice significant differences between the sexes. 


\begin{tabular}{|c|c|c|}
\hline \multicolumn{3}{|l|}{ Biological profile } \\
\hline Laboratory tested parameter (mean \pm SD) & $\begin{array}{l}\text { Peripheral blood (at the time of CRT } \\
\text { implant) }\end{array}$ & $\begin{array}{l}\text { Peripheral blood (at 6-9 months after } \\
\text { the implant) }\end{array}$ \\
\hline Hemoglobin $(\mathrm{mg} / \mathrm{dL})$ & $13,75 \pm 1,49$ & $13,55 \pm 1,77$ \\
\hline Hematocrit (\%) & $40,55 \pm 4,07$ & $39,75 \pm 4,85$ \\
\hline Blood glucose (mg / dL) & $102 \pm 23,35$ & $102,5 \pm 33,39$ \\
\hline $\mathrm{HDL}(\mathrm{mg} / \mathrm{dL})$ & $42 \pm 14,73$ & $42 \pm 17,56$ \\
\hline $\mathrm{LDL}(\mathrm{mg} / \mathrm{dL})$ & $88,5 \pm 44,11$ & $87,25 \pm 39,51$ \\
\hline $\mathrm{BT}(\mathrm{mg} / \mathrm{dL})$ & $128 \pm 59,84$ & $106,5 \pm 53,46$ \\
\hline Total cholesterol (mg/ dL) & $151 \pm 47,56$ & $155 \pm 50,13$ \\
\hline ALT (U / L) & $21,25 \pm I I, 53$ & $18,2 \pm 13,5$ \\
\hline AST (U / L) & $20,05 \pm 4,58$ & $20,5 \pm 8,72$ \\
\hline Uric acid (mg / dL) & $7,32 \pm 2,46$ & $7,05 \pm 1,87$ \\
\hline Urea $(\mathrm{mg} / \mathrm{dL})$ & $51 \pm 29,03$ & $51 \pm 32,95$ \\
\hline Creatinine clearance $\left(\mathrm{mL} / \mathrm{min} / 1.73 \mathrm{~m}^{2}\right)$ & $53 \pm 23,38$ & $53 \pm 23,32$ \\
\hline
\end{tabular}

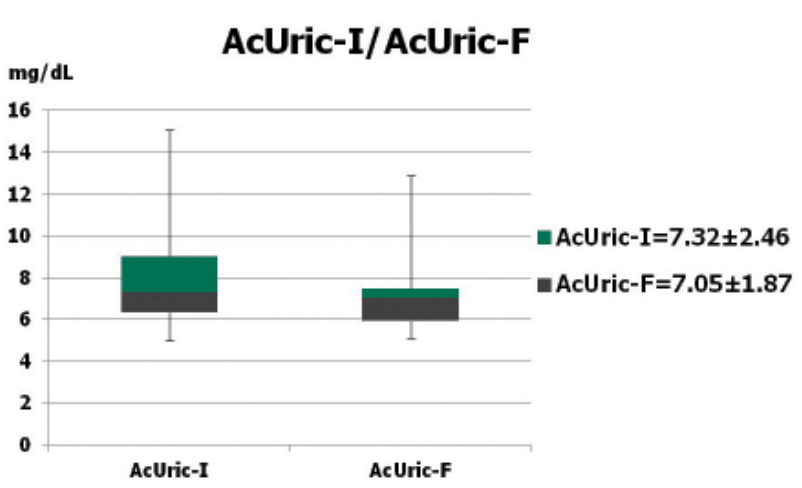

Figure 3. Dynamics of serum uric acid levels in the studied patient group.

\section{Study of the status of the responder / non- responder to cardiac resynchronization therapy}

The chosen criterion for considering a patient as a responder to CRT was a post-interventional increase of the left ventricle ejection fraction (LV) EF, with at least $5 \%$, determined by cardiac ultrasound. However, the definition of responders vs. non-responders after cardiac resynchronization therapy is a non-standardized assessment in literature $e^{16,18,27,28}$ and should take

\section{CreatClearance-I/CreatClearance-F}

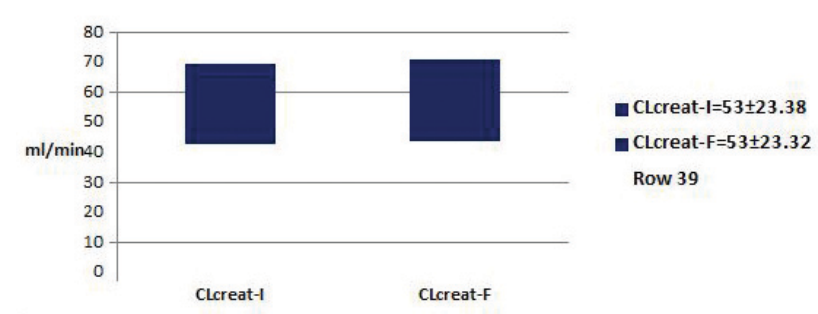

Figure 4. Renal function balance at the moment of the implant and at follow-up. into account several clinical and laboratory elements, such as those listed below:

- „surrogate” clinical objectives: NYHA functional class, 6MWT, quality of life;

- „hard” clinical objectives: morbidity / mortality indices;

- reverse-remodeling echocardiography parameters: EF, EndSystolic/Diastolic LV volume, Mitral valve regurgitation, left atrium volume, mechanical asynchrony parameters (assessed by ultrasound, cardiac MRi, or other methods ${ }^{29,30,31,32}$ ).

Nevertheless, most of the authors of the major impact relevant studies use the dynamics of the echocardiographically evaluated LV ejection fraction. This is seen as a raw parameter easier to assess in daily practice $^{16,18,22,43}$

Applying this echocardiographic parameter, to which we added the need of at least one NYHA class unit decrease in terms of clinical benefit, we assessed a number of 15 patients as clear responses to therapy (52\% of all patients included in the study). What is particularly noteworthy is the fact that 4 of the total of 6 patients with AF, undergoing the intervention, proved to be respondents, which, within the limits of this small group of patients, brings a favorable argument for the inclusion of these patients in the group of those proposed for CRT. It is worth mentioning the unclear and sometimes contradictory data seen in literature ${ }^{1,33,34,35}$ regarding this subject.

Regarding the morbidity / mortality indices, during the follow-up period the average number of hospitalizations was 3, which corresponds to a number of I hospitalization / year; as expected, a higher number of hospitalizations was noted in the case of patients with complicated evolution (observing a maximum of 7 hospitalizations / 3 years of follow-up). 


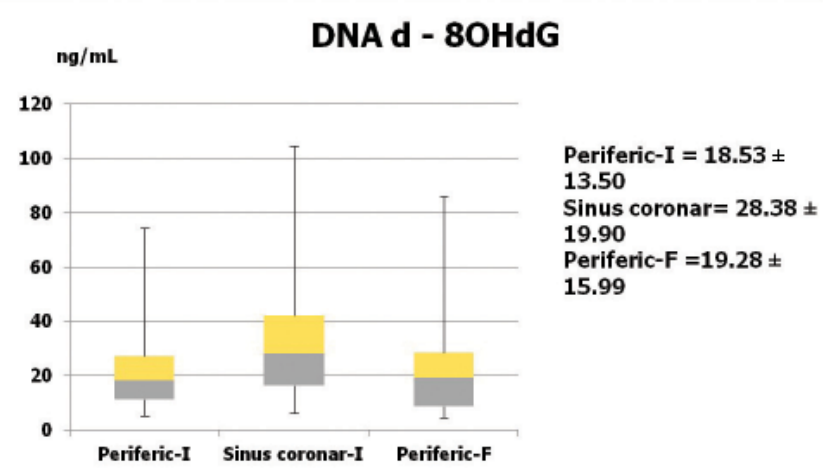

Figure 5. The results of the plasmatic levels of oxidized DNA, according to the 3 distinct moments of sampeling (periferic blood, coronary sinus, and periferic blood after 6-9 months).

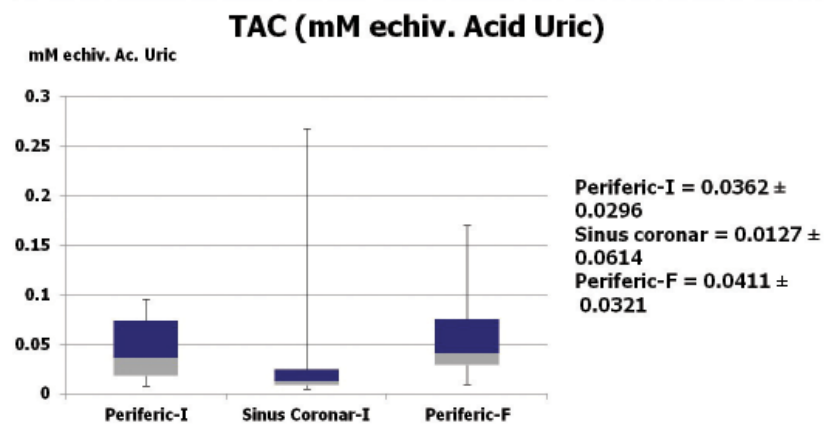

Figure 6. TAC assessment at the 3 moments of sampling.

In our group of patients, 3 died by the end of the follow-up period. One of them was part of the group of respondents.

\section{Evaluation of oxidative stress biomarkers in the studied population}

8-hydroxydeoxyguanosine $(8-\mathrm{OHdG})$ is a marker of oxidative DNA damage. In the study group, we notice that the lowest 8-OHdG value was measured in the peripherally collected blood at the moment of resynchronization. The value increases slightly in peripherally collected blood at 6 months post-intervention. Oxidized DNA is significantly increased $(p<0.05)$ in the blood collected from the coronary sinus at the time of surgery, meaning increased oxidative stress at the time of surgery (Figure 5).

The total antioxidant capacity (TAC) collected from the coronary sinus has the lowest value compared to the blood collected from the periphery before and at 6 months post-intervention, correlating with the increased value of oxidized DNA (Figure 6).

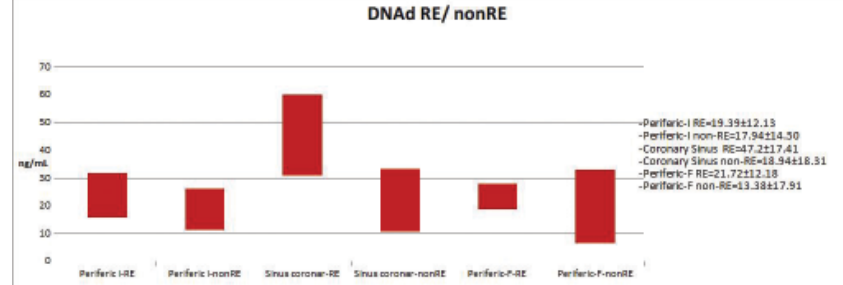

Figure 7. Plasma levels of oxidized DNA in patients with HF and CRTresponders and non-responders.

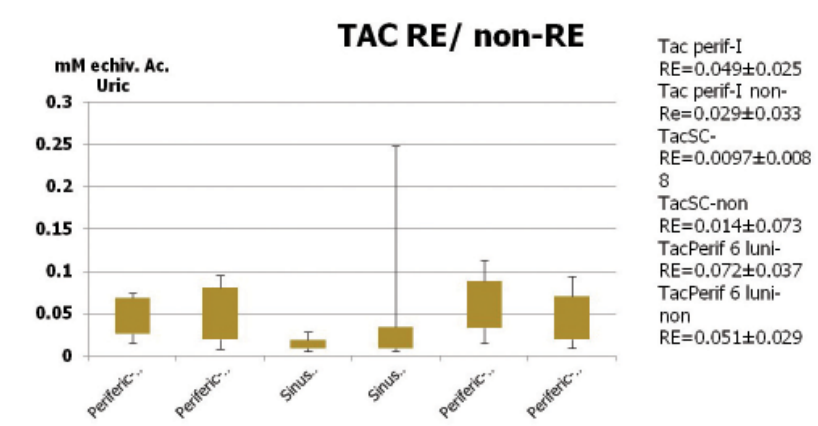

Figure 8. Total antioxidant capacity in responders and non-responders to CRT.

Oxidized DNA measured in blood collected from the coronary sinus has a statistically significant increased value in the future responder patients $(p<0.0 I)$. Oxidized DNA collected from the coronary sinus from non-responder patients does not differ statistically significantly from oxidized DNA collected from peripheral blood (Figure 7).

The total antioxidant capacity in the blood collected from the coronary sinus in future responder patients has a significantly lower value compared to nonresponders and with the initial and final evaluations of peripheral blood. This low value is inversely proportional to the value of oxidized DNA in future responder patients (Figure 8).

In this study we described a novel bio-marker - in terms of extracellular damaged DNA - with possible impact in the CRT candidate selection. In the studied cohort, in the case of responders group (defined by more than $5 \%$ improvement of the EF and one NYHA class downgrading), we notice high levels of damaged DNA of cardiac origin (sampled from the coronary sinus blood). We would like to emphasize that this clearly separates this group from all the other groups of patients for whom 8-OHdG was measured and analyzed. DNAd 8-OHdG was independently related with response to device therapy, having superior dis- 
criminative ability in comparison to other usual clinical variables (such as cardiac ultrasound characteristics or EKG measurements). The use of TAC was intended as a checking method for the DNAd 8-OHdG assessment, as it is well known that in REDOX system there is a balance between cellular and extracellular oxidative and antioxidative agents ${ }^{15,18,20,35,36}$. When misbalance occurs, this is due to insufficient levels of the antioxidative system agents or to the presence of high, overwhelming, pro-oxidative reactions ${ }^{11,14,23,25,37,38}$. Either-way it is expected to see a laboratory picture of high oxidative agents and low antioxidative capacities when disbalance occurs. Our results are clearly pointing to this. There is a clear correlation between high levels of oxidized products in the CS plasma and low values of TAC in the responder group, ensuring a good validation of the lab measurements we performed.

The use of certain biomarkers to predict response to therapy represents a cornerstone in modern electrophysiology struggle $\mathrm{e}^{39,40}$. It is estimated that up to one third of CRT receivers fail to respond to therapy. Conventional prediction criteria (echo, ECG, other imaging methods) failed to improve the response rate to $C R T^{1,6,8}$. In our extended framework, the newly considered biomarker - DNAd 8-OHdG determined in the blood of the coronary sinus - if validated in a large cohort study, could be a response to the unreliable selection of the CRT candidates we currently use $^{41,42}$. Peripheral assessment of damaged DNA proved to be of no use, mainly because of its mixture with oxidated DNA of other origin. For practical reasons, this should not be a major inconvenient, if we take into account that all patients evaluated for the causes of DCM and all the candidates for CRT do benefit from coronary angiography prior to implant. At this moment, we could add to the procedure, the catheterization of CS. A blood sample could be obtained in this way and assessed for damaged DNA. We could, thus, avoid deploying an expensive device to a patient who will not benefit from it, or even worse, which could bring additional procedural risks and long term complications. The results of our study should be interpreted within the boundaries of its design. Human sample size was not sufficient to yield $80 \%$ power, except for large effects, or to provide adequate precision for odds ratio estimates. As a consequence of limited data, we used left ventricular ejection fraction as the major criteria to define response instead of more elaborate parameters as left atrium enlargement, end-systolic and end-diastolic volumes, mitral valve regurgitation and other reverse-remodeling parameters. Because of the limited number of patients, more refined clinical aspects regarding hospitalization or deaths in high damaged DNA patients, are difficult to be formulated, but a direct relationship between this patients, their positive response to CRT and a reduced number of hospitalization is clearly distinguishable in our cohort. Of course, many scientific questions, including the best method of plasma DNAd 8-OHdG assessment, techniques of normalization, and reference profiles in healthy individuals, need clarification before bringing this novel biomarker into the clinical practice. Our data supports the hypothesis established by recent studies that clinically useful extracellular damaged DNA or RNA may be functionally implicated in heart failure pathogenesis ${ }^{1,2}$. Oxidized DNA or mRNA appears to be dynamically regulated by the mechanical stretch of the cardiomyocite on the one hand and the number of viable cardiac cells on the other ${ }^{4,5}$. In other words the amount of oxidized products determined in the cardiac venous blood is dependent of the contractile reserve and the amount of cardiac fibrosis. The fewer the viable cardiomycites, the less measurable is the damaged DNA in cardiac extracted plasma ${ }^{4,5}$. These patients are less likely to reverse-remodel and consequently are candidates for non-response to $\mathrm{CRT}^{43}$. Of course, these are mainly theoretical hypothesis that need further research. The scientific literature regarding these subjects is quite poor. Using the widely used scientific search engines, we were able to identify a relatively small number of articles regarding oxidative stress in heart failure with less than 5 publications regarding this topic and CRT. Among those, only a few speak about the assessment of oxidative compounds in arterial coronary blood in acute ischemic heart disease I and only one takes into account specific measurements from the venous CS in humans ${ }^{2}$.

\section{CONCLUSIONS}

Heart failure (HF) patient selection for Cardiac Resynchronization Therapy (CRT) continues to be a real issue nowadays and still needs improvement. UP to $35 \%$ of CRT patients are currently non-responders to therapy. New bio-markers could be helpful in identifying CRT responders, before procedure. The assessment of damaged DNA from peripheral blood prior and after intervention showed no specific pattern and no obvious evolution, both in responders and non-responders. By contrast, the level of dama- 
ged DNA taken from the coronary sinus identified a clear and distinct population - almost all responders to therapy seemed to have greater levels of Damaged DNA in contrast with the non-responder population. As expected, TAC was lower in the responder group vs. non-responders. Our theory is that greater levels of damaged DNA should be present in heart failures with high percent of remaining viable myocardium. On the contrary, hearts with extensive fibrosis/scar with no or very little viable myocardium are unable to produce high quantities of damaged DNA due to the lack of active cardiac fibers. These patients are less likely to reverse-remodel and consequently are candidates for non-response to CRT. There was no correlation between oxidative stress observed in peripheral and central cardiac blood. DNAd 8-OHdG and TAC measured from coronary sinus plasma could be a new biomarker to identify responders to CRT, but it needs further research. According to our study, peripheral oxidative stress markers seem to be of no use.

Acknowledgements: ,This work received financial support through the project entitled "CERO - Career profile: Romanian Researcher", grant number POSDRU/I59/I.5/S/I35760, cofinanced by the European Social Fund for Sectoral Operational Programme Human Resources Development 2007-2013"

Conflict of interest: none declared.

\section{References}

I. Amaury Edgardo Mont'Serrat Ávila Souza DiasI, MD, MSc; Petr Melnikov2, PhD; Lourdes Zélia Zanoni Cônsolol, MD, PhD. Braz J Cardiovasc Surg Oxidative stress in coronary artery bypass surgery 20I5;30(4):4I7-24.

2. Yonathan F. Melman, MD, PhD et al. Circulating MicroRNA-30d is Associated with Response to Cardiac Resynchronization Therapy in Heart Failure and Regulates Cardiomyocyte Apoptosis: A Translational Pilot Study. Circulation. 2015 June 23; I3I(25): 2202-22I6. 3. Wojciech Krupal, Małgorzata Rozwodowska2, Sławomir Sielskil, Ewa Czarnecka-Żaba3, Tomasz FabiszakI, Gerard Drewa3, Michał KasprzakI, Jacek Kubical. Influence of cardiac resynchronization therapy on oxidative stress markers in patients with chronic heart failure Cardiology Journal 2014, Vol. 21, No. 5, 576-582.

4. Hamza Sunmanl, Adem Özkan2, Hikmet Yorgun3, U ur Canpolat3, Erdem Karabulut4, Tülin Bayrak5, Ergün Barıș Kaya3, Lale Tokgözo lu3, Necla Özer3, Asuman Özkara6, Kudret Aytemir3, Ali Oto3. Evaluating the effects of cardiac resynchronization therapy on pathophysiological pathways of heart failure using surrogate biomarkers. Cardiology Journal 20I8, Vol. 25, No. I, 42-5I.

5. Tsutsui H, Ide T, Shiomi T, Kang D, Hayashidani S, Suematsu N, Wen J, Utsumi H, Hamasaki N, Takeshita A. 8-oxo-dGTPase, which prevents oxidative stress-induced DNA damage, increases in the mitochondria from failing hearts. Circulation 104: 2883-2885, 2001.

6. Scherrer-Crosbie M, Ullrich R, Bloch KD, Nakajima H, Nasseri B, Aretz HT, Lindsey ML, Vancon AC, Huang PL, Lee RT, Zapol WM, Picard $\mathrm{MH}$. Endothelial nitric oxide synthase limits left ventricular remodeling after myocardial infarction in mice. Circulation 104: 1286I291, 200।

7. Sawyer DB, Colucci WS. Mitochondrial oxidative stress in heart failure: "oxygen wastage" revisited. Circ Res 86: I19-120, 2000.
8. Sawyer DB. Oxidative stress in heart failure: what are we missing? Am J Med Sci 342: 120-124, 201

9. Ruetten H, Dimmeler S, Gehring D, Ihling C, Zeiher AM. Concentric left ventricular remodeling in endothelial nitric oxide synthase knockout mice by chronic pressure overload. Cardiovasc Res 66: 444-453, 2005.

10. Ide T, Tsutsui H, Hayashidani S, Kang D, Suematsu N, Nakamura K, Utsumi H, Hamasaki N, Takeshita A. Mitochondrial DNA damage and dysfunction associated with oxidative stress in failing hearts after myocardial infarction. Circ Res 88: 529-535, 200 I.

II. Finkel T. Oxidant signals and oxidative stress. Curr Opin Cell Biol I 5: 247-254, 2003

12. Dhalla AK, Hill MF, Singal PK. Role of oxidative stress in transition of hypertrophy to heart failure. J Am Coll Cardiol 28: 506-5I4, 1996.

13. Creemers EE, Cleutjens JP, Smits JF, Daemen MJ. Matrix metalloproteinase inhibition after myocardial infarction: a new approach to prevent heart failure? Circ Res 89: 20I-210, 200I

14. Cingolani HE, Plastino JA, Escudero EM, Mangal B, Brown J, Perez NG. The effect of xanthine oxidase inhibition upon ejection fraction in heart failure patients: La Plata Study. J Card Fail 12: 49I-498, 2006

15. Cesselli D, Jakoniuk I, Barlucchi L, Beltrami AP, Hintze TH, NadalGinard B, Kajstura J, Leri A, Anversa P. Oxidative stress-mediated cardiac cell death is a major determinant of ventricular dysfunction and failure in dog dilated cardiomyopathy. Circ Res 89: 279-286, 2001.

16. Cappola TP, Kass DA, Nelson GS, Berger RD, Rosas GO, Kobeissi ZA, Marban E, Hare JM. Allopurinol improves myocardial efficiency in patients with idiopathic dilated cardiomyopathy. Circulation |04:2407-24 I I, 200।.

17. Strauss, D. G., Selvester, R. H., Wagner, G. S. Defining left bundle branch block in the era of cardiac resynchronization therapy. Am. J. Cardiol. 201 I;50: I |29-4।

18. Chung, E. S.Results of the Predictors of Response to CRT (PROSPECT) trial. Circulation 2008;54:56-82.

19. Gasparini, M. Long-term survival in patients undergoing cardiac resynchronization therapy: the importance of performing atrio-ventricular junction ablation in patients with permanent atrial fibrillation.Eur. Heart. J.2008; I4: I 29-40.

20. Stellbrink, C. Impact of cardiac resynchronization therapy using hemodynamically optimized pacing on left ventricular remodeling in patients with congestive heart failure and ventricular conduction disturbances. J. Am. Coll. Cardiol. 2001;38:21-36.

21. C. Ginghină. Mic tratat de cardiologie. Ed. Academiei Române. 2010; 679-737.

22. Auricchio, A., Prinzen, F. W.Non-responders to cardiac resynchronization therapy: the magnitude of the problem and the issues.Circ. J. $2011 ; 65: 40-72$.

23. Cleland, J. G. The effect of cardiac resynchronization on morbidity and mortality in heart failure. N. Engl. J. Med. 2005;

24. Gorcsan, J.Echocardiography for cardiac resynchronization therapy: recommendations for performance and reporting - a report from the American Society of Echocardiography Dyssynchrony Writing Group endorsed by the Heart Rhythm Society.J. Am. Soc. Echocardiogr. 2008; 19:55-60.

25. Mascioli, G. Electrocardiographic criteria of true left bundle branch block: a simple sign to predict a better clinical and instrumental response to CRT. Pacing Clin. Electrophysiol. 2012; I 2 1:54-6 I

26. Seo, Y. The role of echocardiography in predicting responders to cardiac resynchronization therapy: results from the Japan Cardiac Resynchronization therapy registry Trial (J-CRT).Circ. J. 201 I;43:5780.

27. Yu, C. M. Tissue Doppler echocardiographic evidence of reverse remodeling and improved synchronicity by simultaneously delaying regional contraction after biventricular pacing therapy in heart failure. Circulation. 2002; 104:448-450.

28. Wilton, S. B., Leung, A. A., Ghali, W. A., Faris, P., Exner, D. V. Outcomes of cardiac resynchronization therapy in patients with versus those without atrial fibrillation: a systematic review and meta-analysis (RAFT). Heart Rhythm.20 I I; 13 
29. Delnoy, P. P. Sustained benefit of cardiac resynchronization therapy.J. Cardiovasc. Electrophysiol. 2007; 12:36-65.

30. Prinzen, F. W., Vernooy, K., Auricchio, A. Cardiac resynchronization therapy: state-of-the-art of current applications, guidelines, ongoing trials and areas of controversy. Circulation 2013;9:47-67

31. Ping Jia, Charulatha Ramanathan, Raja N. Ghanem, Kyungmoo Ryu, Niraj Varma. Electrocardiographic imaging of cardiac resynchronization therapy in heart failure: Observation of variable electrophysiologic responses. Heart Rhythm. 2006; 3(3): 296-310.

32. Linde, $\mathrm{C}$. Long-term impact of cardiac resynchronization therapy in mild heart failure: 5-year results from the REsynchronization reVErses Remodeling in Systolic left vEntricular dysfunction (REVERSE) study.Eur. Heart J.2013;12:524-530.

33. Saxon, L. A. Influence of left ventricular lead location on outcomes in the COMPANION study QRS duration. J. Cardiovasc. Electrophysiol. 2009;84: I I36-I I 44.

34. Cleland JG, Daubert JC, Erdmann E, Freemantle N. The CARE-HF study (CArdiac REsynchronisation in Heart Failure study): rationale, design and end-points. Eur J Heart Fail. 200I;3(4):48I-9.

35. Hsu, J. C. Predictors of super-response to cardiac resynchronization therapy and associated improvement in clinical outcome: the MADIT-CRT (multicenter automatic defibrillator implantation trial with cardiac resynchronization therapy) study. J. Am. Coll. Cardiol. 2012;59:2366-73.
36. Anthony S.L. Tang, George A. Wells, Mario Talajic. Cardiac-Resynchronization Therapy for Mild-to-Moderate Heart Failure. The New England Journal of Medicine. 2010; 363(25): 2385-2395.

37. Frank Ruschitzka, William T. Abraham et all. Echocardiography Guided Cardiac Resynchronization Therapy (EchoCRT) trial in patients with narrow QRS and ventricular dyssynchrony-Cardiac-Resynchronization Therapy in Heart Failure with a Narrow QRS Complex. N Engl J Med. 20I3; 369:1395- I 405.

38. Cazeau S, Leclercq C, Lavergne T. Multisite Stimulation in Cardiomyopathies (MUSTIC) Study Investigators. N Engl J Med. 200I; 344(I2):873-80.

39. Strik, M. Transseptal conduction as an important determinant for cardiac resynchronization therapy, as revealed by extensive electrical mapping in the dyssynchronous canine heart. Circ. Arrhythm. Electrophysiol. 2013;2-23

40. Vernooy, K. Left bundle branch block induces ventricular remodelling and functional septal hypoperfusion. Eur. Heart. J. 2005;3:91-98

41. Sawhney, N. S.Randomized prospective trial of atrioventricular delay programming for cardiac resynchronization therapy. Heart Rhythm. 2004; I22-133.

42. Cheuk-Man Yu et al. Cardiac Resynchronization Therapy, 2nd Edition.2008; 28-43 43. 2013 ESC Guidelines on cardiac pacing and cardiac resynchronization therapy. Eur Heart J. 20I3;34:228I-2329. 